\title{
Postsurgical Paracicatricial Cutaneous Satellitosis of Giant Cell Tumour of the Tendon Sheath, Localized Type
}

\author{
V. Caputo ${ }^{a}$ S. Fiorella ${ }^{a}$ E. Orlando \\ Departments of a Dermatology and ${ }^{b}$ Human Pathology, University of Palermo, \\ Palermo, Italy
}

\section{Key Words}

Tenosynovial giant cell tumour $\cdot$ Cutaneous satellitosis $\cdot$ Malignant transformation

\begin{abstract}
Tenosynovial giant cell tumour (localized type) is a tumour of tendon sheaths and interphalangeal joints, affecting the digits and arising from the synovium. It is characterized by a proliferation of mononuclear cells and osteoclast-like polykaryocytes. Its propagation to the skin is an exceptional event, which can take place either in localized form in the fingertips (localized type) or in the rare diffuse form called giant cell tumour of the tendon sheath (diffuse type). We report here a case of giant cell tumour with cutaneous satellites, which appeared close to and around the surgical scar following the excision of the primary lesion, in a 9-year-old boy. In the cutaneous satellites, a few signs of transformation could be observed, consisting of the lack of stroma and pronounced cellularity characterized by sheets of rounded synovial-like cells admixed with multinucleated giant cells and xanthoma cells. No relapse was observed 1 year after a plastic surgery procedure (complete replacement of the involved skin). Diffuse lesions usually represent a diagnostic problem in comparison with their localized counterparts. The malignant transformation of an originally typical tenosynovial giant cell tumour is a rare but well-documented event. Our case seems to represent a typical example because the pronounced cellularity might wrongly lead to a diagnosis of malignancy.
\end{abstract}

\section{Introduction}

Tenosynovial giant cell tumour, localized type, occurs in the synovial tendon sheath or, more rarely, in the articular synovia, and mostly affects the hand [1]. It typically appears in adults, as a bulging, clearly visible and palpable nodule, typically not attached to the underlying skin, and more often adjacent to an interphalangeal joint. Although easily seen 
upon dermatological observation, it is not a primitive cutaneous neoformation and it hardly propagates to the skin, unless when localized at the finger tips where the dermis closely adheres to the underlying tissues [2,3]. Skin involvement is the result of diffusion by contiguity, and this event must be distinguished from malignant giant cell tumour of the tendon sheath, which is a very rare event secondary to a locoregional hematogenous metastasization [4].

We report here a case of cutaneous satellitosis with a certain typical histological appearance in a morphologically benign tenosynovial giant cell tumour, localized type, observed in a 9-year-old boy.

\section{Case Report}

A 9-year-old male patient presented with disseminated asymptomatic papular/nodular lesions around a linear surgical scar that ran longitudinally along the lateral side of the first metacarpal (fig. 1). The lesions, 3-4 mm in diameter, were ruby-red coloured, with a smooth and shiny surface, and hardelastic to the touch. The scar was the result of a surgical procedure, performed 1 year earlier, to excise a subcutaneous nodule localized in the proximity of the carpal-metacarpal lateral joint. The tumour was connected to the tendon by the long abductor of the thumb. It had been erroneously diagnosed histologically as tendinous xanthoma. The patient was in good health and all his blood results, including cholesterol level and triglycerides, were within the normal range.

The skin dissemination had started 6 months after the surgical procedure, and the lesions had progressively increased in size. The histology of one of them (ig. 2) showed a circumscribed proliferation focus which occupied the upper and mid dermis, consisting of a cell population characterized by multinucleated giant cells, mononuclear and inflammatory cells. Multinucleated giant cells were scattered throughout the lesions and these cells, which were generated by the fusion of the more prevalent mononuclear cells, had variable numbers of nuclei. The stroma was scant and silver staining revealed a paucity of reticulin fibers. Rare mitotic, nonatypical figures were present. The newlyformed tissue was richly vascularized, and punctuated by small clefts resulting from a loss of intercellular cohesion.

The tumour spread, and it did not appear circumscribed. It raised the epidermis and formed a dome-shaped bulging, flattening the lower profile without a grenz zone. Some nests of tumour cells were observed in the deep dermis close to the main focus. In the available specimen of the original lesion (fig. 3), which of course did not include the whole lesion, no capsule was visible. No pleomorphism was present and the nucleoli were hardly visible, whilst the giant cells were smaller and lower in number than in the cutaneous satellitosis. Here again, despite the low number of extravasated erythrocytes, deposits of hemosiderin were observed only focally. The clefts in the tissue were broad and numerous. No xanthomatous cells were observed. From an immunohistochemical point of view, both the mononuclear cells and polykaryocytes were positive for CD68 (PK1) (fig. 4).

The following diagnosis was thus made: tenosynovial giant cell tumour, localized type, with postsurgery paracicatricial cutaneous satellitosis. MRI was performed on the affected region, ruling out a deep recurrence; after that the patient was referred to a plastic surgery department, where all skin of the region involved was replaced with full-thickness grafts stemming from the patient's forearm and thigh. One year later, no signs of relapse were observed.

\section{Discussion}

Tenosynovial giant cell tumour, localized type, is a benign tumour of the tendon or joint synovial membranes most commonly affecting the hands, typically proximal to an interphalangeal joint. It can appear at any age; however, it is more frequent between 30 and 50 years of age $[5,6]$. Synovial origin seems to be confirmed by positivity to 
immunohistological markers of the normal synoviocytes, although these markers are equally expressed by the cells of the monocyte-macrophagic system [7-9].

The neoformation consists of a proliferating focus of cells with an elliptical nucleus and a broad circular cytoplasm, which mirrors the morphology of synoviocytes and bizarre giant cells, being intensely eosinophilic and provided with numerous nuclei, scattered or clustered centrally or peripherally, or along the periphery. A variable number of siderophages is associated, together with inflammatory cells and, sometimes, xanthomatous cells.

Unlike giant cell tumour of the tendon sheath, diffuse type, which originates from the large joints and their bursae, and propagates freely into the soft tissues, the localized type is, for the most part, contained in a dense connective capsule, in continuity with the tendon's sheath, from which septa depart, penetrating the newly formed tissue. The existence of a rare malignancy, so much debated and contested, is nowadays accepted as long as this definition is restricted to the rare lesions characterized by declaredly malignant areas in the framework of benign tenosynovial giant cell tumour, or to histologically and biologically malignant areas of originally typical lesions $[1,4,10-12]$. This allows the ruling out of a variety of sarcomas with a giant-cell component which, in their infiltration process, can aggress tendons and their sheaths. Among them, namely, the malignant fibrohistiocytoma.

In our case, which, among other reasons, stands out for the early age at onset, the histopathology of the original lesion can be related to the benign form of neoplasia and must therefore be differentiated from its mimics that can accidentally be found in a tendon. If the quota of foamy cells is relevant, the picture might recall that of tendinous xanthoma, which nevertheless is lodged in the tendon's body, rather than in the synovial space, and contains numerous cholesterol clefts along with a more conspicuous inflammatory component. The problem of histopathological distinction with this lesion is merely theoretical, since tendinous xanthoma is associated with hereditary hyperlipemia type IIa (hypercholesterolemia with LDL increase), and is typically multiple.

Unlike tenosynovial tumour, the solitary reticulohistiocytoma appears almost exclusively in adults, and it primarily originates in the dermis. From a histological point of view, it differs in the intense eosinophilia of its mononucleated elements (oncocytic histiocytes), and in its polykaryocytes with the typical ground-glass cytoplasm. Fibroma of the tendon sheath, which, like giant cell tumour, shows preferential localization in the hands, can also show some similarity only to the hyalinized forms of giant cell tumor, since it consists of a sparse population of fusiform cells (rather than circular), lodged in an abundant eosinophilic and hyalinized stroma.

Finally, giant cell tumour of soft tissue with low malignant potential has to be considered; today it is believed to be the counterpart of giant cell bone tumour of soft tissue, which typically localizes in the arm or hand, and that can manifest at any age. Cytologically, though very similar to tenosynovial tumour, it differs from it because it diffusedly infiltrates the host tissues and does not contain siderophages or xanthomatous cells, whilst it can present with areas of bone metaplasia [13].

Having ruled out mimics, the diagnosis of tenosynovial giant cell tumour could thus be confirmed with postsurgical paracicatricial cutaneous satellitosis. The latter represents the outcome of a locoregional dissemination, which is the expression of a transformation of 
the lesion from a localized type to a diffuse type, despite the innocent histology of both lesions. The acquisition of this competence is a landmark in the evolution of the neoplasia and it is matched by a major change in the histological picture observed in the foci of cutaneous colonization. Indeed, these lesions (cutaneous foci) show evident signs of transformation, represented by the lack of stroma, by the presence of pleomorphism and bulging nucleoli, and by thick vascularization.

Nevertheless, the degree of atypia is low, and the cells preserve their normal immunohistological positivity, whilst the rare - and not atypical - mitotic figures observed have a poor prognostic value, since in the benign form a good 3 per 10 highpower fields have been described [14]. Lastly, no necrotic areas are observed. The picture, therefore, only partly seems to overlap with that of malignant tenosynovial giant cell tumour, in which the neoplastic progression was likely identified at its onset.

From a practical point of view, these lesions (cutaneous satellitosis) should be regarded as locally aggressive but non-metastasizing lesions, and the absence of signs of relapse 1 year later is indicative of that.

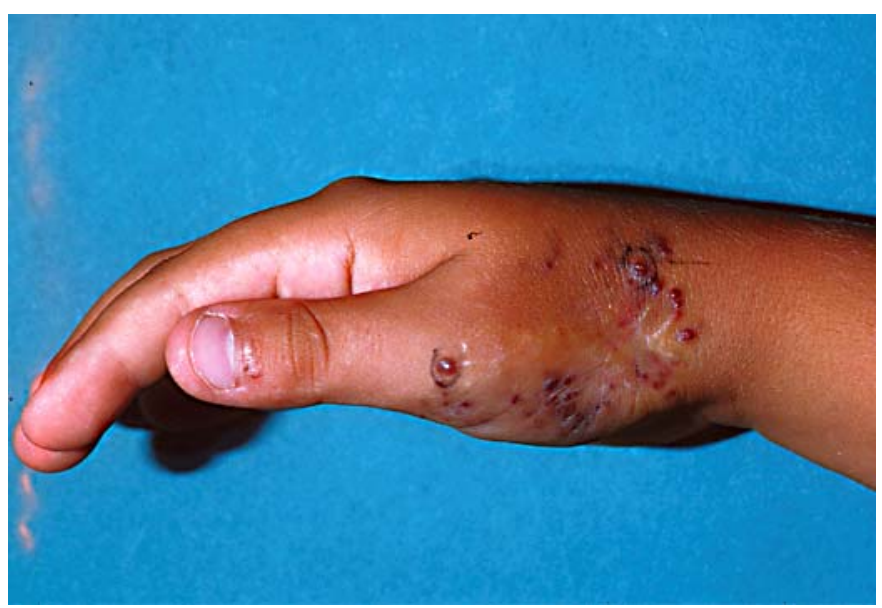

Fig. 1. Paracicatricial cutaneous dissemination of ruby-red papular-nodular scars. 


\begin{tabular}{r|l|l|l}
$\begin{array}{c}\text { Case Reports in } \\
\text { Dermatology }\end{array}$ & $\begin{array}{l}\text { Case Rep Dermatol 2011;3:118-123 } \\
\text { DOI: } 10.1159 / 000328999\end{array}$ & $\begin{array}{l}\text { Published online: } \\
\text { May 27, 2011 }\end{array}$ & $\begin{array}{l}\text { I 2011 S. Karger AG, Basel } \\
\text { ISSN 1662-6567 } \\
\text { www.karger.com/cde }\end{array}$ \\
\hline
\end{tabular}

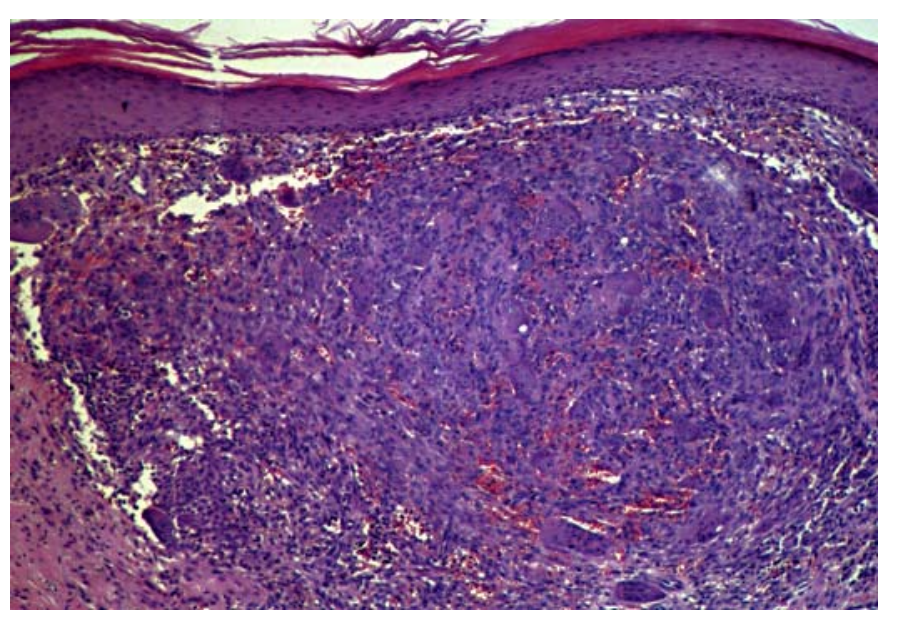

Fig. 2. Lobulated mass with numerous multinucleated giant cells, histiocytes and inflammatory cells. HE, 10 $\times$.

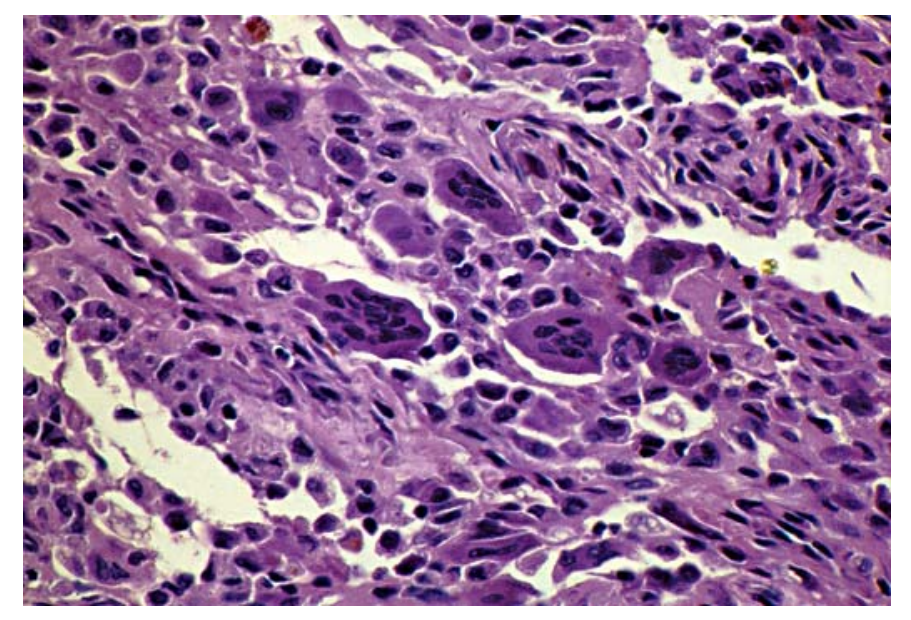

Fig. 3. Multinucleated giant cells and histiocytes. HE, 40×. 


\begin{tabular}{|c|c|c|c|}
\hline $\begin{array}{l}\text { Case Reports in } \\
\text { ermatology }\end{array}$ & $\begin{array}{l}\text { Case Rep Dermatol 2011;3:118-123 } \\
\text { DOI: } \underline{10.1159 / 000328999}\end{array}$ & $\begin{array}{l}\text { Published online: } \\
\text { May 27, } 2011\end{array}$ & $\begin{array}{l}\text { @ } 2011 \text { S. Karger AG, Basel } \\
\text { ISSN } 1662-6567 \\
\text { www.karger.com/cde }\end{array}$ \\
\hline
\end{tabular}

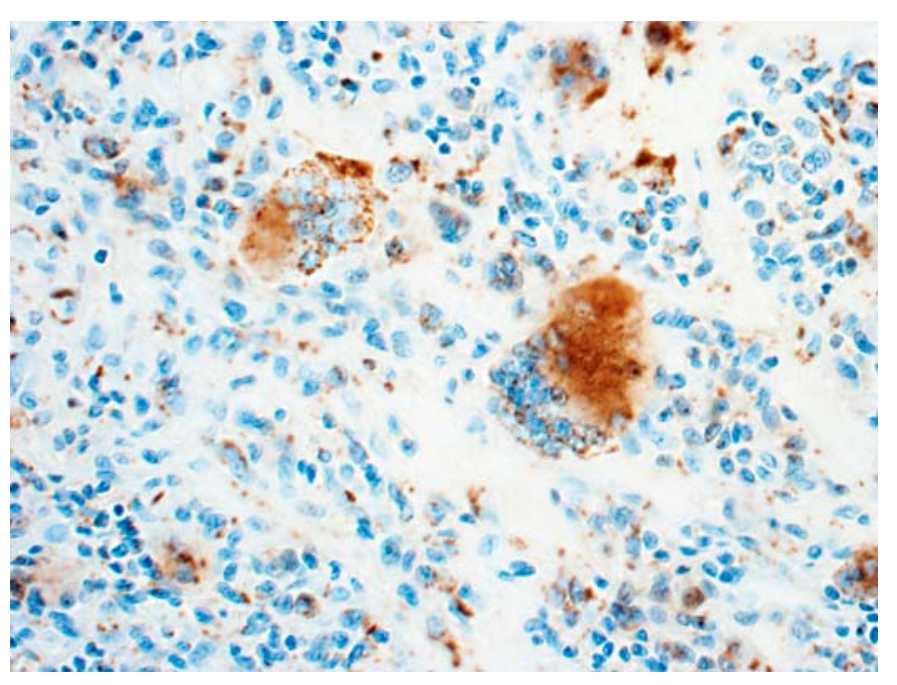

Fig. 4. CD68-positive giant cell. IHC, 40×.

\section{References}

1 Weiss SW, Goldblum JR: Benign tumors and tumor-like lesions of synovial tissue; in: Weiss SW, Goldblum JR, Enzinger FM (eds): Enzinger and Weiss's Soft Tissue Tumors. Mosby, 2007, pp 769-788.

$\checkmark 2$ Rustin MHA, Robinson TWE: Giant-cell tumour of the tendon sheath - an uncommon tumour presenting to dermatologists. Clin Exp Dermatol 1989;14:466-468.

3 King DT, Millman AJ, Gurevitch AW, Hirose FM: Giant cell tumor of the tendon sheath involving skin. Arch Dermatol 1978;114:944-946.

-4 Castens HP, Howell RS: Malignant giant cell tumor of tendon sheath. Virchows Arch A Pathol Anat Histol 1979;382:237-243.

5 Sapra S, Prokopetz R, Murray AH: Giant cell tumor of tendon sheath. Int J Derm 1989;28:587-590.

6 Bastian BC, Kuchler A, Brocker EB: Der benigne Riesenzelltumor der Sehnenscheide. Hautarzt 1994;45:385388.

7 O'Connell JX, Fanburg JC, Rosenberg AE: Giant cell tumor of tendon sheath and pigmented villonodular synovitis: immunophenotype suggests a synovial cell origin. Hum Pathol 1995;26:771-775.

-8 Maluf HM, De Young BR, Swanson PE, Wick MR: Fibroma and giant cell tumor of tendon sheath: a comparative histological and immunohistological study. Mod Pathol 1995;8:155-159.

-9 Cavaliere A, Sidoni A, Bucciarelli E: Giant cell tumor of tendon sheath: immunohistochemical study of 20 cases. Tumori 1997;83:841-846.

10 Choong PF, Willen H, Nilbert M, Mertens F, Mandahl N, Carlen B, Rydholm A: Pigmented villonodular synovitis. Monoclonality and metastasis - a case for neoplastic origin? Acta Orthop Scand 1995;66:64-68.

-11 Somerhausen NS, Fletcher CD: Diffuse-type giant cell tumor: clinicopathologic and immunohistochemical analysis of 50 cases with extraarticular disease. Am J Sur Pathol 2000;24:479-492.

12 Shinjo K, Miyake N, Takahashi Y: Malignant giant cell tumor of the tendon sheath: an autopsy report and review of the literature. Jpn J Clin Oncol 1993;23:317-324.

13 Folpe AL, Morris RJ, Weiss SW: Soft tissue giant cell tumour of low malignant potential: a proposal for the reclassification of malignant giant cell tumour of soft parts. Mod Pathol 1999;12:894-902.

14 Rao AS, Vigorita VJ: Pigmented villonodular sinovitis (giant cell tumor of the tendon sheath and synovial membrane): a review of 81 cases. J Bone Joint Surg 1984;66:76-94. 